\title{
PENGEMBANGAN DATABASE EVALUASI KINERJA DOSEN BERBASIS ANDROID DI STKIP PGRI LUBUKLINGGAU
}

\author{
Armi Yuneti ${ }^{1}$, Hamdan ${ }^{2}$, Donni Pestalozi ${ }^{3}$, M. Rusni Eka Putra ${ }^{4}$, Rudi Erwandi ${ }^{5}$ \\ STKIP PGRI Lubuklinggau ${ }^{1,2,3,4,5}$ \\ Armi2019@gmail.com ${ }^{1}$
}

\begin{abstract}
ABSTRAK
Tujuan penelitian ini adalah untuk mengelola database kinerja dosen berbasis android. Pendekatan dalam penelitian ini menggunakan pendekatan system dengan model waterfall. Langkah-langkah pengembangan model yakni; 1) requirements analysis, 2) design, 3) implementation and unit testing. 4) integration and system test. Hasil penelitian, hasil validasi ahli database meliputi; program studi, dosen, mata kuliah, kelas, mahasiswa, dan laporan layak digunakan. Validasi ahli website dilakukan terhadap 5 indikator, yakni; a) content, b) readibility, c) speed, d) kecanggihan teknologi, dan e) akses layak digunakan. Simpulan, Implementasi database kinerja dosen berbasis android layak untuk digunakan.
\end{abstract}

Kata Kunci: Android, Database, Kinerja Dosen

\begin{abstract}
The purpose of this research is to manage an android-based lecturer performance database. The approach in this study uses a systems approach with a waterfall model. The steps in developing the model are; 1) requirements analysis, 2) design, 3) implementation and unit testing. 4) integration and system test. The results of the study, the results of the database expert validation include; study programs, lecturers, courses, classes, students, and reports are appropriate to use. Website expert validation is carried out on 5 indicators, namely; a) content, b) readibility, c) speed, d) technological sophistication, and e) access worth using. Conclusion, Implementation of android-based lecturer performance database is feasible to use.
\end{abstract}

Keywords: Android, Database, Lecturer Performance 


\section{PENDAHULUAN}

Salah satu tugas dan tanggung jawab dosen, sebagaimana diamanatkan dalam Peraturan Pemerintah No.12 tahun 2012 tentang Pendidikan Tinggi, adalah melaksanakan proses pembelajaran. Tugas tersebut merupakan utama seorang dosen yang harus dilaksanakan dengan sungguh-sungguh karena sebagai realisasi dari tugas utama suatu perguruan tinggi, yaitu melaksanakan kegiatan proses pembelajaran dalam upaya mendidik mahasiswa. Disamping kegiatan pembelajaran dosen juga berkewajiban melakukan kegiatan penelitian dan pengabdian pada masyarakat. Kinerja dosen pada suatu perguruan tinggi merupakan perilaku nyata yang ditampilkan setiap dosen sebagai prestasi kerja yang dihasilkan oleh dosen tersebut sesuai dengan peranannya (Velmourougan, Davachelvan, 2010; Fathasyah, 2016).

Lembaga melakukan evaluasi terhadap kinerja dosen. Kinerja dosen yang dievaluasi meliputi Tri Dharma perguruan tinggi yaitu pendidikan, penelitian dan pengabdian pada masyarakat. Evaluasi Tri Dhrama ini diharapkan bermanfaat untuk memperbaiki mutu dosen itu sendiri serta memperbaiki proses perkuliahan dari mata kuliah yang diampunya. Seiring perkembangan teknologi informasi, maka pengelolaan evaluasi kinerja dosen dapat dikelola dengan sistem informasi manajemen database berbasis online. Hasil penelitian Mahmudi (2015) aplikasi dengan informasi hasil evaluasi kinerja dosen yang digunakan sebagai dasar untuk melakukan perbaikan kinerja maupun sebagai dasar dalam pemberian reward untuk dosen.

Kemudian hasil penelitian Rochman et al.,(2015) memudahkan dalam menilai kinerja setiap dosen dan meminimalkan penggunaan kertas pada kuisioner, sehingga dapat mengatasi masalah-masalah yang ada pada sistem yang berjalan sebelumnya. Aplikasi pengembangan database evaluasi kinerja dosen sangatlah membantu lembaga dalam menilai kinerja dosen baik kinerja pengajaran, penelitian dan pengabdian pada masyarakat Selama ini di STKIP PGRI Lubuklinggau penilaian kinerja dosen dilakukan secara manual, dengan cara menyebarkan instrument angket kepada mahasiswa untuk menilai dosen pengampu mata kuliah. Penilaian secara manual dirasakan kurang efektif sebab 1) memakan waktu cukup lama untuk input data dan analisa hasil angket, 2) banyak menggunakan kertas, sehingga budget untuk membeli kertas cukup tinggi, 3) tingkat kejujuran pengisi diragukan, sering ditemukan beberapa angket diisi oleh satu orang mahasiswa. Dengan pola manual penyebaran angket kinerja dosen dirasakan kurang efektif dan efisien, maka dengan ini direncang program pengembangan database evaluasi kinerja dosen berbasis android, sehingga pengelolaan hasil evaluasi kinerja dosen dapat dilakukan secara cepat, tepat dan akurat.

Spesifikasi database evaluasi kinerja dosen meliputi; 1) pengelolaan database kinerja dosen dikembangkan dengan prinsip pengembangan multimedia, dengan mengintegrasikan hyperteks, hyperlink dan hypermedia untuk membantu sistem penyampaian; 2) database kinerja dosen dikelola dengan metode query, metode ini mampu melacak data; 3) database kinerja dosen yang diinput dapat disimpan dalam hardisk komputer server. 


\section{METODE PENELITIAN}

Pendekatan dalam penelitian ini menggunakan pendekatan system dengan model waterfall. Langkah-langkah pengembangan model yakni; 1) requirements analysis, 2) design, 3) implementation and unit testing. 4) integration and system test. Adapun tahapan-tahapan tersebut dapat dijelaskan sebagai berikut:

Requirements Analysis. Proses ini mencari dan menganalisis kebutuhan dari keseluruhan sistem yang akan diaplikasikan ke dalam bentuk software.

Design. Proses ini digunakan untuk mengubah kebutuhan-kebutuhan diatas menjadi representasi ke dalam bentuk "blueprint" software sebelum coding dimulai. Desain harus dapat mengimplementasikan kebutuhan yang telah disebutkan pada tahap sebelumnya.

Implementation and unit testing. Untuk dapat dimengerti oleh mesin, dalam hal ini adalah komputer, maka desain tadi harus diubah bentuknya menjadi bentuk yang dapat dimengerti oleh mesin, yaitu ke dalam bahasa pemrograman melalui proses coding. Tahap ini merupakan implementasi dari tahap design yang secara teknis nantinya dikerjakan oleh programmer.

Integration and system test. Pada fase ini sistem di uji coba melalui telaah pakar, sehingga dapat diketahui kekurangan sistem yang telah dirancang.

\section{HASIL PENELITIAN}

Analisis Kebutuhan

Analisis kebutuhan yang dilakukan meliputi pengumpulan data tentang pengelolaan database kinerja dosen. Kemudian peneliti melakukan wawancara kepada dosen dan mahasiswa untuk mendapatkan data tentang pengelolaan database kinerja dosen. Hasil survey awal peneliti terhadap 30 responden yang terdiri dari dosen dan mahasiswa masih menggunakan sistem manual, $80 \%$ rata-rata responden menjawab (ya) pengelolaan data kinerja dosen secara manual. Pengelolaan data secara manual memperlambat data kinerja dosen, seperti pelacakan data kinerja dosen memerlukan penelusuran dokumen ataupun membongkar-bongkar dokumen, hal ini dapat memakan waktu lama untuk menemukan dokumen yang diinginkan, 2) penyimpanan data kinerja secara manual beresiko terhadap kejadian banjir, kebakaran, dan kerusakan dokumen terhadap hewan (rayap, kecoak ataupun serangga) yang dapat merusak data sekolah yang disimpan dalam dokumen yang berbahan dasar kertas

\section{Desain SIM Database Kinerja Dosen}

Berdasarkan analisis kebutuhan, maka sangatlah penting untuk didesain system informasi manajemen database kinerja dosen. Berikut flowchart database kinerja dosen 


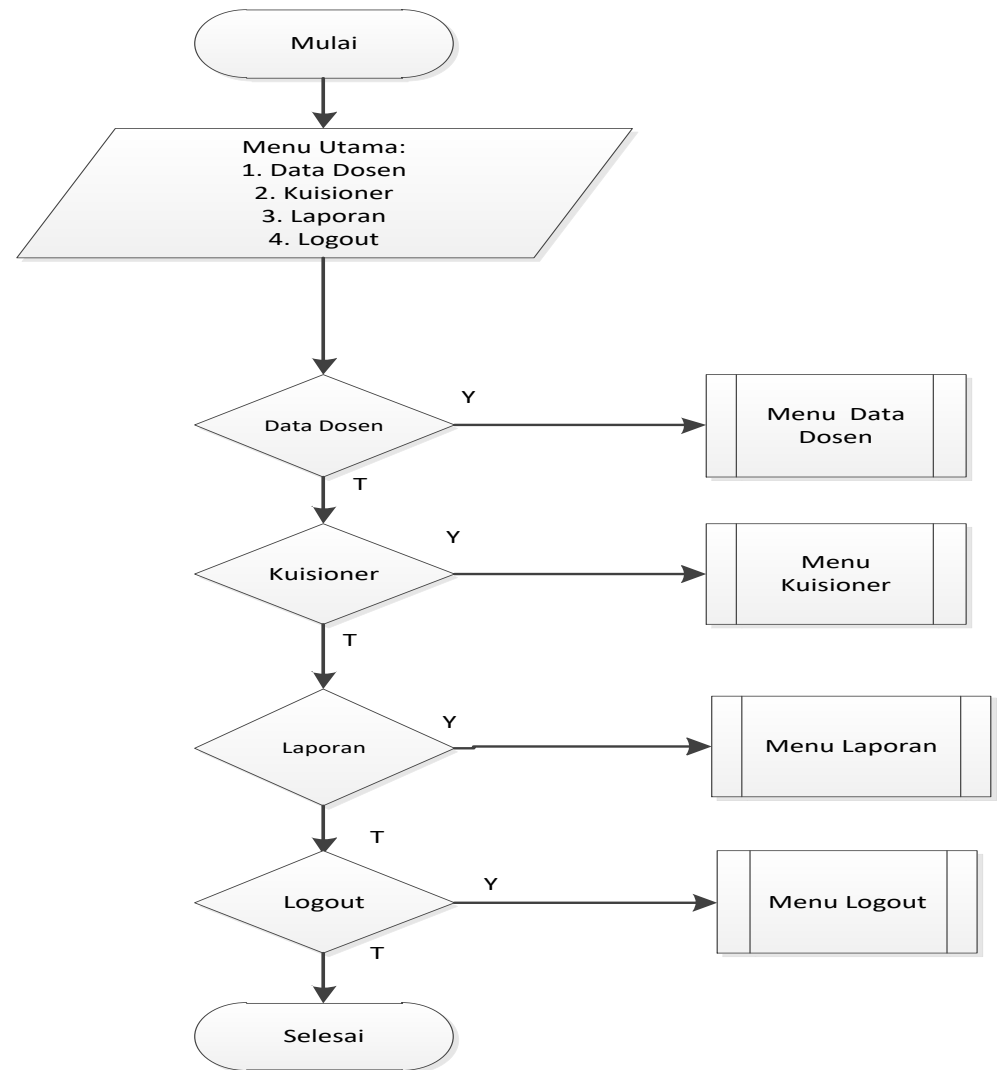

Gambar 1 Flowchart Database Kinerja Dosen

\section{Implementasi}

\section{Program Studi}

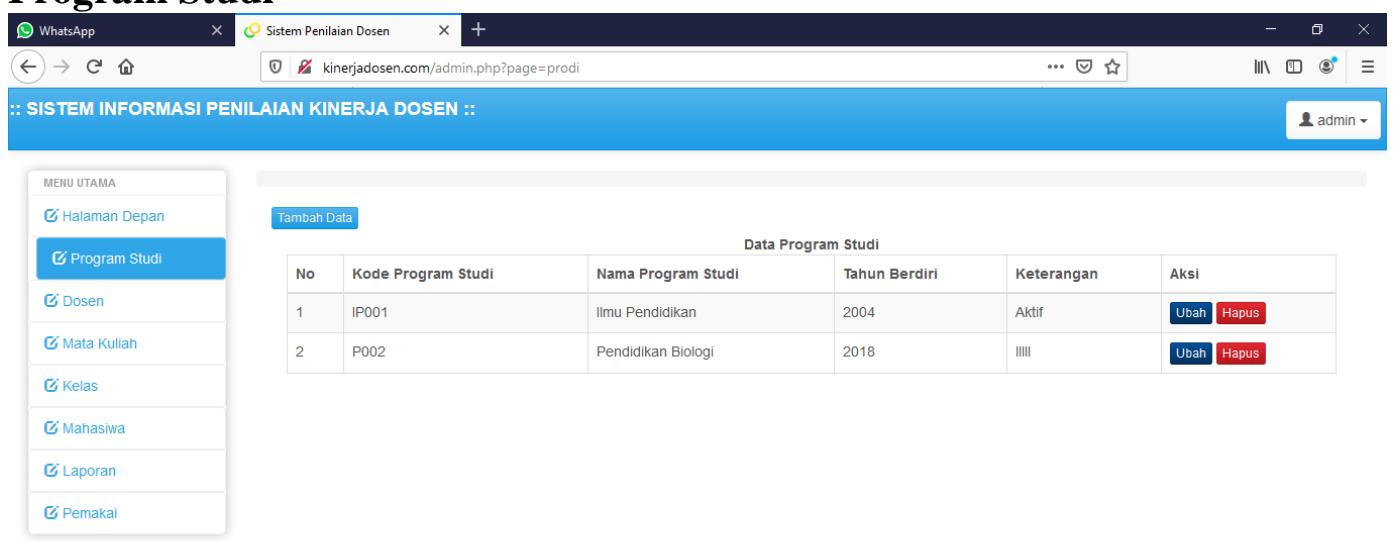




\section{Dosen}

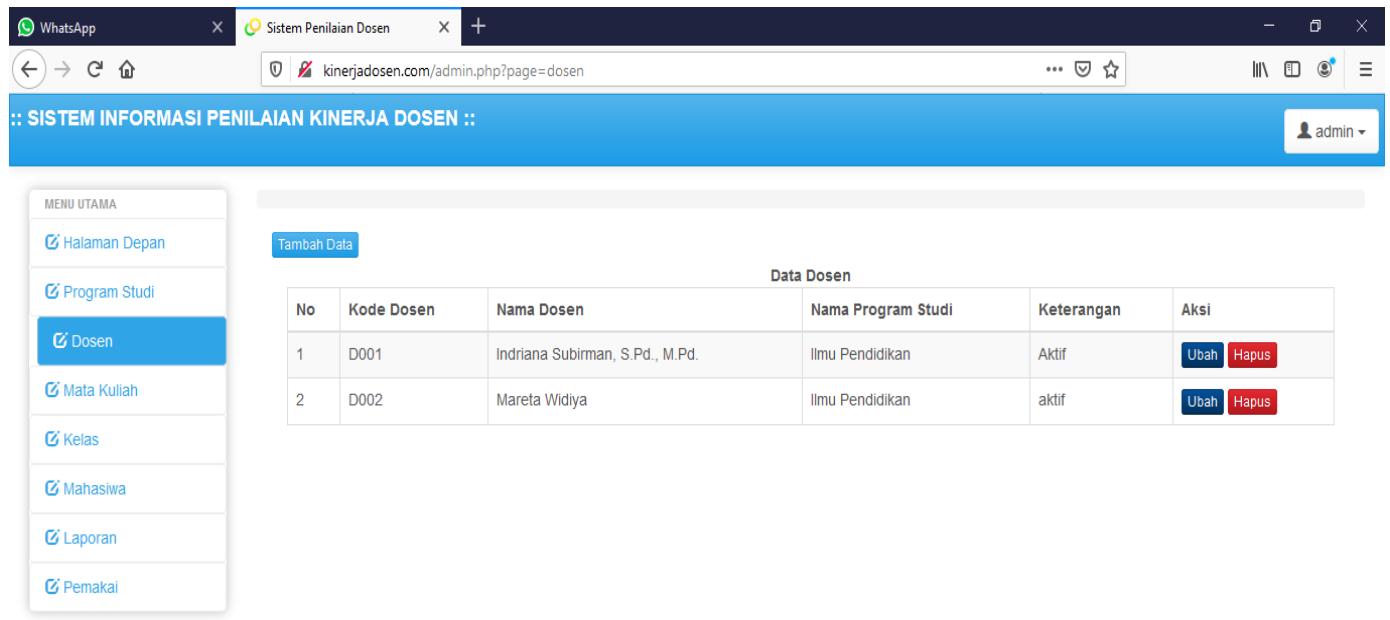

\section{Gambar 3 Menu Dosen}

\section{Mata Kuliah}

\begin{tabular}{|c|c|c|c|c|c|c|}
\hline \multirow{2}{*}{$\begin{array}{l}\text { (2) WhatsApp } \\
\leftarrow \rightarrow C \text { A }\end{array}$} & \multicolumn{2}{|c|}{ Sistem Penilaian Dosen } & & & & $-\quad 0$ \\
\hline & \multicolumn{3}{|c|}{ (1) \& kinerjadosen.com/admin.php?page=matakuliah } & & .. 田自 & IIII $\mathbb{9} 9^{\circ}$ \\
\hline \multicolumn{6}{|c|}{ :: SISTEM INFORMASI PENILAIAN KINERJA DOSEN :: } & 2 admin \\
\hline \multicolumn{7}{|l|}{ MELU UTAMA } \\
\hline C Halaman Depan & \multicolumn{6}{|c|}{ Tambah Data } \\
\hline CP Program Stud & \multicolumn{6}{|c|}{ Data Matakuliah } \\
\hline 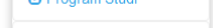 & No & Kode Matakuliah & Nama Matakuliah & SKS & Program Studi & Aksi \\
\hline $\mathbb{C}$ Dosen & 1 & MKD001 & Pendidikan Kewarganegaraan & 3 & IImu Pendidikan & Ubah Hapus \\
\hline G Mata Kuliah & 2 & k009 & Pancasila & 3 & IImu Pendidikan & Ubah Hapus \\
\hline \multicolumn{7}{|l|}{$\mathbb{C}$ Kelas } \\
\hline \multicolumn{7}{|l|}{$\mathscr{C}$ Mahasiwa } \\
\hline \multicolumn{7}{|l|}{ E Laporan } \\
\hline ๔ Pemakai & & & & & & \\
\hline
\end{tabular}

Gambar 4 Menu Mata Kuliah 


\section{Kelas}

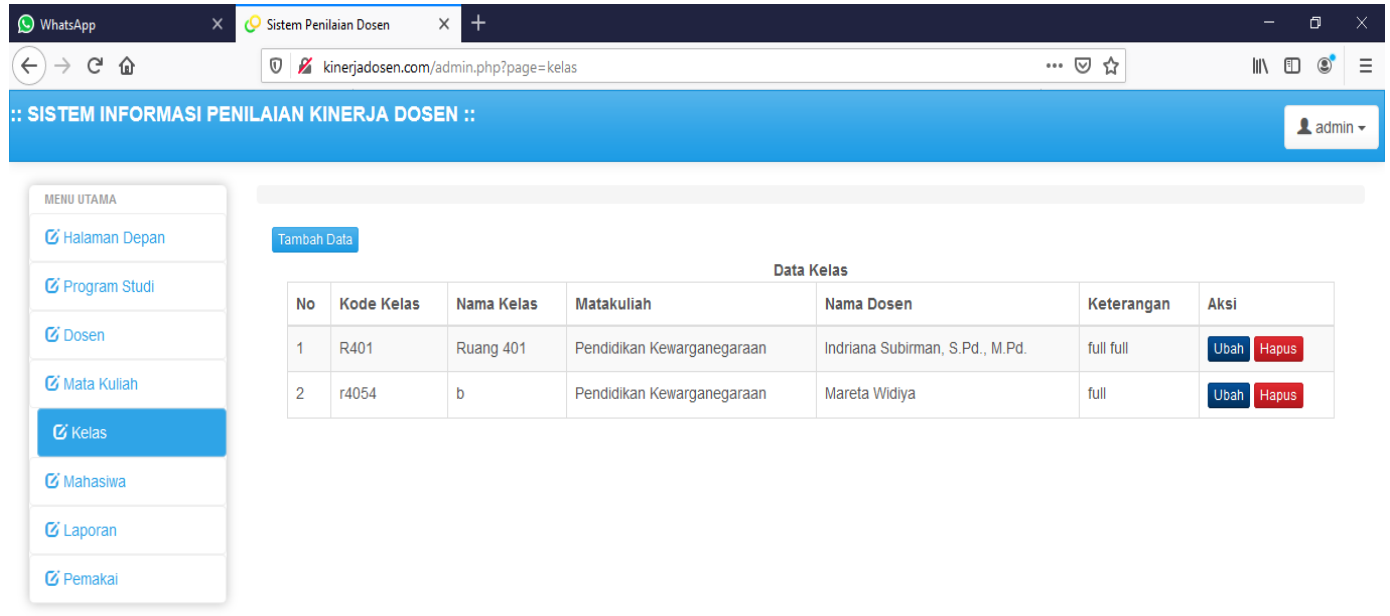

\# $\mathrm{O}$ Type here to search

苛

Gambar 5 Menu Kelas

\section{Mahasiswa}

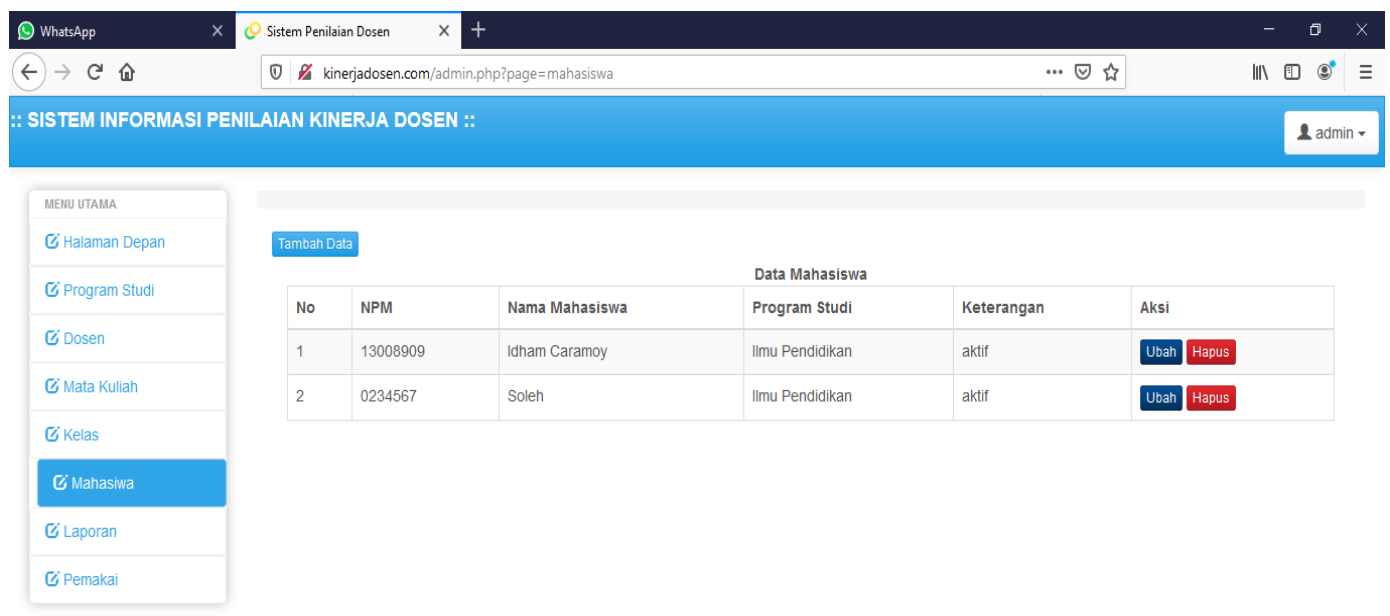




\section{Laporan}

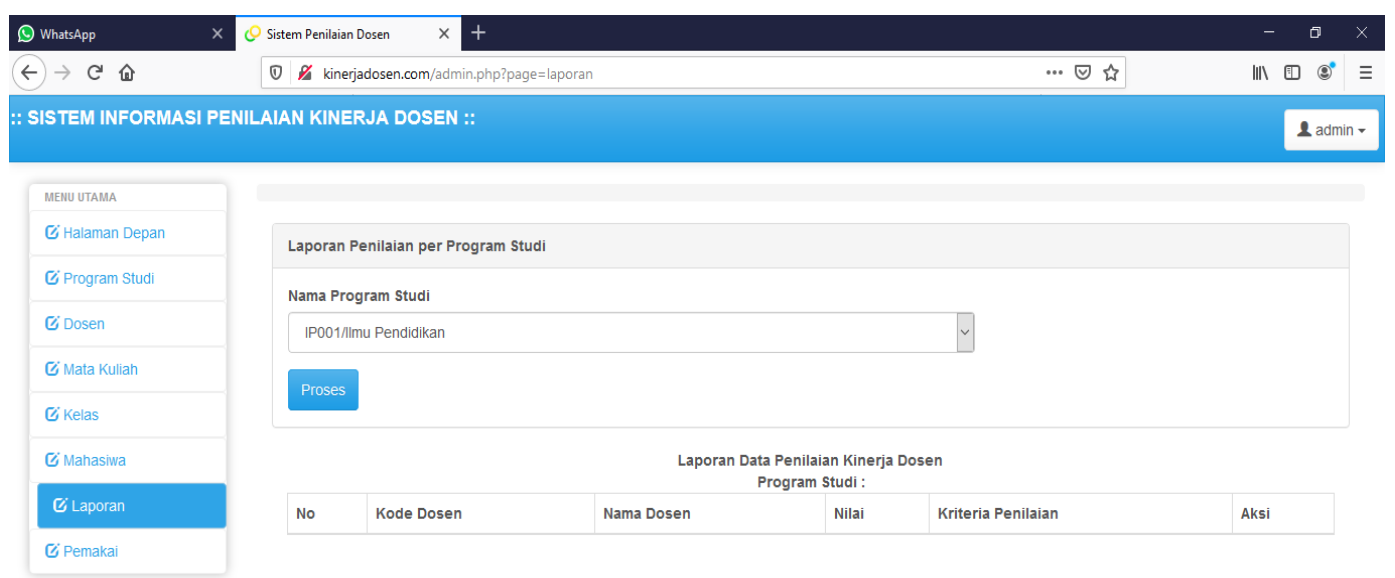

\section{Gambar 7 Menu Laporan}

\section{Telaah Pakar}

\section{Ahli Database}

Ahli database mengevaluasi integrasi menu dan submenu dari produk yang dikembangkan. Hasil validasi dilakukan untuk melihat kelayakan integrasi menu dan submenu database kinerja dosen. Hasil validasi ahli database meliputi; program studi, dosen, mata kuliah, kelas, mahasiswa, dan laporan.

Kelayakkan komponen dan subkomponen program studi. Berdasarkan hasil validasi komponen dan subkomponen program studi layak untuk digunakan. Kelayakan komponen dan subkomponen dosen. Berdasarkan hasil validasi komponen dan subkomponen dosen layak untuk digunakan. Kelayakan komponen dan subkomponen mata kuliah. Berdasarkan hasil validasi, komponen dan subkomponen mata kuliah layak untuk digunakan. Kelayakan komponen dan subkomponen kelas . Berdasarkan hasil validasi ahli, komponen dan subkomponen kelas layak untuk digunakan. Kelayakan komponen dan subkomponen mahasiswa. Berdasarkan hasil validasi ahli, komponen dan subkomponen mahasiswa layak untuk digunakan. Kelayakan komponen dan subkomponen laporan. Berdasarkan hasil validasi ahli, komponen dan subkomponen laporan layak untuk digunakan.

\section{Ahli Website}

Ahli website mengevaluasi system pelaksanaan database kinerja dosen yang dikembangkan secara online. Hasil validasi dilakukan untuk melihat kelayakan system database sekolah yang dilaksanakan secara online. Validasi ahli website 
dilakukan terhadap 5 indikator, yakni; a) content, b) readibility, c) speed, d) kecanggihan teknologi, dan e) akses.

Content. Berdasarkan hasil validasi content SIM Databse Kinerja Dosen sudah layak untuk digunakan, karena sudah memuat menu dan submenu yang dibutuhkan oleh pengguna.

Readibility. Berdasarkan hasil validasi readibilty SIM Database Kinerja Dosen layak untuk digunakan, sehingga pengguna dalam hal ini admin dapat mengoperasikannya dengan baik.

Speed. Berdasarkan hasil validasi, speed (kecepatan) SIM Database Kinerja Dosen layak untuk digunakan, sehingga pengguna dapat mengakses dengan baik.

Kecanggihan Teknologi. Berdasarkan hasil validasi, kecanggihan teknologi SIM Database Kinerja Dosen cukup baik dan layak untuk digunakan, sehingga pengguna dapat mengakses di sekolahnya masing-masing dalam memberikan laporan perkembangan sekolah.

Akses. Berdasarkan hasil validasi, akses SIM Database Kinerja Dosen cukup baik, sehingga pengguna dapat dengan mudah untuk terkoneksi.

\section{PEMBAHASAN}

Berdasarkan telaah pakar baik dari pakar database dan website, maka dapat dinyatakan SIM Database Kinerja Dosen Berbasis Android layak untuk digunakan. Seiring perkembangan teknologi informasi, maka pengelolaan evaluasi kinerja dosen dapat dikelola dengan sistem informasi manajemen database berbasis online. Hasil penelitian Mahmudi (2015) aplikasi dengan informasi hasil evaluasi kinerja dosen yang digunakan sebagai dasar untuk melakukan perbaikan kinerja maupun sebagai dasar dalam pemberian reward untuk dosen. Kemudian hasil penelitian Rochman et al., (2015) memudahkan dalam menilai kinerja setiap dosen dan meminimalkan penggunaan kertas pada kuisioner, sehingga dapat mengatasi masalah-masalah yang ada pada sistem yang berjalan sebelumnya.

Kemudian hasil penelitian Rochman et al., (2015) memudahkan dalam menilai kinerja setiap dosen dan meminimalkan penggunaan kertas pada kuisioner, sehingga dapat mengatasi masalah-masalah yang ada pada sistem yang berjalan sebelumnya. Aplikasi pengembangan database evaluasi kinerja dosen sangatlah membantu lembaga dalam menilai kinerja dosen baik kinerja pengajaran, penelitian dan pengabdian pada masyarakat Selama ini di STKIP PGRI Lubuklinggau penilaian kinerja dosen dilakukan secara manual, dengan cara menyebarkan instrument angket kepada mahasiswa untuk menilai dosen pengampu mata kuliah. Penilaian secara manual dirasakan kurang efektif sebab 1) memakan waktu cukup lama untuk input data dan analisa hasil angket, 2) banyak menggunakan kertas, sehingga budget untuk membeli kertas cukup tinggi, 3) tingkat kejujuran pengisi diragukan, sering ditemukan beberapa angket diisi oleh satu orang mahasiswa. Dengan pola manual penyebaran angket kinerja dosen dirasakan kurang efektif dan efisien, maka dengan ini direncang program pengembangan database evaluasi kinerja dosen berbasis android, sehingga pengelolaan hasil evaluasi kinerja dosen dapat dilakukan secara cepat, tepat dan akurat. 
Aplikasi pengembangan database evaluasi kinerja dosen sangatlah membantu lembaga dalam menilai kinerja dosen baik kinerja pengajaran, penelitian dan pengabdian pada masyarakat Selama ini di STKIP PGRI Lubuklinggau penilaian kinerja dosen dilakukan secara manual, dengan cara menyebarkan instrument angket kepada mahasiswa untuk menilai dosen pengampu mata kuliah. Penilaian secara manual dirasakan kurang efektif sebab 1) memakan waktu cukup lama untuk input data dan analisa hasil angket, 2) banyak menggunakan kertas, sehingga budget untuk membeli kertas cukup tinggi, 3) tingkat kejujuran pengisi diragukan, sering ditemukan beberapa angket diisi oleh satu orang mahasiswa. Dengan pola manual penyebaran angket kinerja dosen dirasakan kurang efektif dan efisien, maka dengan ini direncang program pengembangan database evaluasi kinerja dosen berbasis android, sehingga pengelolaan hasil evaluasi kinerja dosen dapat dilakukan secara cepat, tepat dan akurat (Kroenke, David, 2017).

\section{SIMPULAN}

Konsep pengambangan terdiri dari program studi, dosen, mata kuliah, kelas, mahasiswa, dan laporan. Desain pengembangan terdiri dari menu dan submenu program studi, dosen, mata kuliah, kelas, mahasiswa, dan laporan. Implementasi SIM Database Kinerja Dosen Berbasis Android layak untuk digunakan.

\section{DAFTAR PUSTAKA}

Fathansyah, F. (2016). Komputer Basis Data. Bandung: Informatika

Kroenke, D. M., \& David, A. J. (2017). Database Concepts. 3rd ed. New York Precentice

Mahmudi, A. (2015). Sistem Informasi Penilaian Kinerja Dosen dan Karyawan Berbasis Web, Jurnal Surya Informatika, 1(1), 55-60

Peraturan Pemerintah Nomor 12 tahun 2012 tentang Pendidikan Tinggi

Rochman A., Hilmi, F \& Ebi, M. (2015). Sistem Informasi Kinerja Dosen pada Universitas Kejuangan 45. Jurnal Sisfotek Global, 5(1), 43-48

Velmourougan, R., \& Davachelvan, K. (2010). Evolving a New Model for Sofware Development Life Sycle. International Journal of Computer Science and Network Security, 10(1) 